May 2012

\title{
An Exploratory Study of Online Information Regarding Colony Collapse Disorder
}

Meredith K. Boehm

University of Tennessee - Knoxville, mboehm@utk.edu

Follow this and additional works at: https://scholarworks.sjsu.edu/ischoolsrj

Part of the Communication Technology and New Media Commons, Library and Information Science Commons, Organizational Communication Commons, Science and Technology Studies Commons, and the Social Influence and Political Communication Commons

\section{Recommended Citation}

Boehm, M. K. (2012). An Exploratory Study of Online Information Regarding Colony Collapse Disorder. School of Information Student Research Journal, 2(1). https://doi.org/10.31979/2575-2499.020104 Retrieved from https://scholarworks.sjsu.edu/ischoolsrj/vol2/iss1/4

This article is brought to you by the open access Journals at SJSU ScholarWorks. It has been accepted for inclusion in School of Information Student Research Journal by an authorized administrator of SJSU ScholarWorks. For more information, please contact scholarworks@sjsu.edu. 


\title{
An Exploratory Study of Online Information Regarding Colony Collapse Disorder
}

\begin{abstract}
The cause or causes of Colony Collapse Disorder (CCD) are uncertain. CCD defines specific characteristics of the nationwide deaths of honey bee colonies in the last decade. Adult bees often disappear from the hive and die, leaving the colony weak and vulnerable to disease. Environmental scientists and agriculturalists have developed many different theories about CCD and its origins. The different theories create challenges regarding the effective dissemination of information about CCD to the different realms of public information seekers. There is a need for an exploration of the online communication of CCD information using federal environmental agency web resources. CCD research information dissemination practices are one example of the trans-disciplinary complexity surrounding many current environmental issues. The study addresses different information "packages" offered or not offered for different types of CCD information seekers. The goal of the study is to inform future research addressing the comprehensive construction of federal e-government science information by finding strengths and weaknesses in the current information landscape of CCD resources on the web.
\end{abstract}

\section{Keywords}

e-government web content, information seekers, uncertainty

\begin{abstract}
About Author
Meredith is a Knoxville, Tennessee native with a bachelor's degree in ceramic arts from the Maryland Institute College of Art in Baltimore, Maryland. Currently preparing to begin doctoral studies in information sciences and communication, Meredith's research interests focus on the intersection of e-government and e-science, citizen involvement in complex scientific problem solving, and the systemic function of large-scale data infrastructures for environmental science research. Meredith has been fortunate to work as a graduate teaching and research assistant for Dr. Vandana Singh and Dr. Dania Bilal as a master's degree student at the University of Tennessee School of Information Sciences. Meredith also performed a role as a paid intern at the Oak Ridge National Laboratory's Distributed Active Archive Center for Biogeochemical Dynamics (DAAC) and contributed to NASA's FLUXNET network database and other climate change data archiving projects at the DAAC. In the future Meredith's goal is to achieve a position as a research professional, publishing scholarly work as a representative of an academic institution and to teach students as a professor of information sciences specializing in science communication studies.
\end{abstract}




\section{An Exploratory Study of Online Information Regarding Colony Collapse} Disorder

In Fall 2006, the National Research Council submitted a report covering the emergence of a phenomenon called Colony Collapse Disorder (CCD). This problem is significant because it affects the pollination of necessary crops and the production of food in America and worldwide. The term CCD defines specific characteristics of the nationwide deaths of honey bee colonies in the last decade. Adult bees often disappear from the hive and die, leaving the colony weak and vulnerable to disease.

At this time there are many web pages, campaigns, and multimedia presentations about CCD available to information seeking citizens, but there is no existing way to identify the main sources of information on the topic. This study will evaluate the landscape of web-based information available that addresses CCD. The purpose of the exploration is to understand the types, topics, and formats of on-line information available to users with specific information needs and to address the comprehensiveness of the information that is available on the web. The study's results will enable discussion about specific strengths and weaknesses of the major entities that provide information about CCD.

\section{Introduction and Statement of the Problem}

Since 2004, farmers and apiculturists (bee experts) across the nation have experienced massive declines in their managed European honey bee populations as a result of CCD. The North American Pollinator Protection Campaign (NAPPC) estimates the loss in the last decade to be between 50 and 90 percent of managed colonies (NAPPC, 2007). This loss has deep implications for the nation and the sustainability of the environment. Honey bees are major pollinators of crops such as almonds, fruit trees, and alfalfa and almost a third of the nation's food supply depends on honey bee pollination. Thus, CCD is of major environmental, agricultural, economic, and political concern. The cause or causes of CCD are uncertain. Environmental scientists and agriculturalists have developed many different theories about $\mathrm{CCD}$ and its origins. With the rise of CCD came a rise in concerns over equitable dissemination of information about CCD to public information seekers.

Frank Fischer's (2000) book, Citizens, Experts and the Environment, introduces the term "wicked" to describe the nature of environmental problems like CCD. "Wicked problems" are defined as being uncertain in cause, having many stakeholders with conflicting interests, and having no foreseeable solution (p. 136). For wicked problems, quality information dissemination becomes essential to ensure public understanding of current research on the "wickedness" 
of the situation. In the face of conflicting expert opinions of empirical research interpretations, such as those surrounding CCD, Fischer notes that citizens rely on their "socio-cultural assessment of the factors" (Fischer, 2000, p.137). Industry, political agendas, and the media shape these socio-culturally constructed views and citizens' understanding of the issues.

The Internet has become the major vehicle for the government to provide the most information to the most people in the shortest amount of time. As Jobe (2006) notes, "technology, in the form of the Internet, has enabled federal agencies and others to deliver detailed data, bibliographic databases, and publications in a cost effective manner" (p. 257). The World Wide Web allows users to explore material from the government (and others) instantaneously through the aid of hyperlinks and downloadable documents. "World Wide Web sites offer several advantages for disseminating information on a fast-changing technical topic, including their global accessibility, and their ability to update information frequently, incorporate multimedia formats, and link to networks of other sites" (Byrne et al., 2002. p. 293). The webpage can lead the user to numerous articles, multimedia applications, and data sets. Despite all the information available, however, an environmental organization or governmental body may not provide a comprehensive picture of a complex and uncertain problem such as CCD to all types of information seekers.

Existing studies explore the information dissemination practices for wildlife agency websites at the state level. These studies address other "wicked problems" similar to CCD, including diseases like Chronic Wasting Disease (Eschenfelder \& Miller, 2007). There is also research regarding the media's coverage of CCD (Cho, 2010). There remains a need for exploration of the online communication of CCD information by environmental agency web resources at the federal level, among other things. CCD is a topic of current interest in the agricultural and biodiversity research fields and the study of CCD information dissemination practices will be applicable to many wicked problems. This study addresses different information "packages" offered for different types of users. The goal of this study is to inform future research addressing construction of federal government science electronic information, by finding strengths and weaknesses in the current information landscape.

\section{Literature Review}

Environmental science communication literature has numerous dimensions that relate to the study of uncertainty, the public sphere, and wicked problems. In postnormal science theory, a concept developed by Funtowicz and Ravetz (1999, 2003), research "focuses on aspects of problem solving that tend to be neglected in traditional accounts of scientific practice: uncertainty, value loading, and a 
plurality of legitimate perspectives" (Funtowicz \& Ravetz, 2003, p.1). Postnormal science recognizes the current disconnect between the scientific community and a public understanding of science. As scientific studies have had less impact on public policy, environmental communications scholars in Europe and worldwide recognized the inherent need for public involvement. In the perspective of post-normal science, the equitability of information dissemination is essential because of the complexity of an issue like CCD, the impact that the issue has on stakeholders, and the value added by citizens giving insight to the problem solving network. Gregory and Miller (1998) state, "for citizens who want to take part in the democratic process of technological society, all the science that they need to know about is controversial; so it is the mess, the disagreements, and the uncertainties of science that matter most to the public sphere" (p.61).

When looking at past practices of government information dissemination and the adoption of the website as the medium of choice for maximum potential citizen engagement, the field of communication lacks studies that evaluate the characteristics of these governmental web pages. To fill that void, this study focuses on the needs of the spectrum of CCD information-seeking citizens and the federal e-government website's role in a network of CCD information providers. This study addresses the need to go beyond the reporting of scientific data to examine the information transmission vehicle, a topic requiring deliberation by those outside of the scientific community.

To understand the term "uncertainty" as it applies to environmental problems like CCD, Maxim and van der Sluijs (2007) conducted a case study of honey bee risk from insecticide. Their paper discusses a proposed information framework, called Knowledge Quality Assessment (KQA). Maxim and van der Sluijs test the KQA framework by applying it to a situation where policy makers are involved in communicating about uncertainty and are invested in fostering cooperation among French stakeholders. The framework to assess the quality of the knowledge importantly assessed the information that the individuals used to engage in deliberation. However, Maxim and van der Sluijs address only one area of CCD and one very specific information user group, so their study does not address the needs of the information seeking public beyond the specific French policy-makers.

Jasanoff (2003) discusses the need for a less objective, more inclusive dimension to science and better public engagement in science communication. Her article, "Technologies of Humility," discusses the incongruencies between ever-increasing access to new technology and the old habits of scholarly hierarchy and exclusion that persist in science and government. Jasanoff proposes "a framework to bring the human elements of morality and subjectivity back into the discussion of science and technology as opposed to the 'Technologies of Hubris' disconnecting science from such human qualities" (p. 240). Her four key elements 
for "technologies of humility"- - technologies that are inclusive to the public as opposed to exclusive-are: framing, vulnerability, distribution, and learning (Jasanoff, 2003). As an editorial on the current socio-cultural treatment of science in the United States, the article describes the status of scientific information available to the public within the realm of a public understanding of science. Her proposal can guide exploration of scientific information dissemination, including in the CCD context. Her philosophy applies to wicked problems in all areas of scientific inquiry, and influences the need for further studies on information resources for wicked problems such as CCD.

Bradshaw and Borchers' (2000) article, "Uncertainty as Information," studies the differences between scientific and government views on uncertainty communication. The study uses the phrase "science-policy gap" to describe the "dysfunctional aspects of the science-policy interface" (Bradshaw \& Borchers, 2000 , p. 2). In particular, the authors examine Intergovernmental Panel on Climate Change (IPCC) reports, applying theories of cognitive dissonance and volition to explain why uncertainty creates doubt and mistrust between groups. Using a scale of increasing complexity and uncertainty, Bradshaw and Borchers chart the types of environmental controversies and where they rate on this scale. CCD information could be evaluated using this scale; however, the dynamics of the public sphere and the industrial sector are left unexamined in this case. This means that important stakeholders are not considered. A more complete analysis is needed to gain a comprehensive perspective.

Cho's (2010) article, "Silence of the Bees," is a survey of media representations of CCD. Cho discusses the differences between the portrayal of the issue in the press and in the scientific scholarly journals. Specifically, Cho engages in content analysis of science journal articles that discuss CCD in contrast to "U.S. prestige press" articles that discuss CCD. In so doing, Cho examines differences in the number of publications, the discussion types, and word choice over the two year period from 2007- 2009.

In a case study on Chronic Wasting Disease (CWD), Eschenfelder and Miller (2007) explore the ways websites transmit text-based environmental information from state wildlife agencies to the public. The study analyzes how information transmission fosters relationships between the government and citizens. The study assesses the variations in scope of text information available on four state websites by employing a specific framework constructed by the authors. Titled the Government Information Valuation (GIV) framework, the information seeking public is placed into specific categories based on their role in the use of information about CWD. Eschenfelder and Miller expand on an earlier proposal that "increased governmental use of technology will lead in part to a period of 'information abundance' facilitating citizen and civil society involvement in governance" (2007, p.64). Eschenfelder and Miller (2007) assert 
that the current level of agency analysis is insufficient because it does not take into account the form and specific content of the documents in relation to the intended audience. The authors make connections between the GIV framework and the information types and topics but clear distinctions are not made regarding the topics per content type. Applying this aspect to the analysis of available information content produces a greater depth to the discussion by taking the content analysis a step further.

The Eschenfelder and Miller study is significant to the exploration of CCD information because of the similarities between CWD and CCD. Both phenomena have highly contested views regarding their causes and initial definitions. Both phenomena influence rules and regulations regarding the treatment of the natural resources within a specific region. Additionally, there are myriad resources on both problems, offering information in different formats and perspectives. The current exploratory study will use the GIV framework to define the public sphere by organizing citizen user groups by role and need. The categories of citizens are: private, attentive, deliberative, and publisher. The similarity between CWD and CCD makes the GIV framework easily adaptable to the needs of the CCD information seekers on the Internet.

For Funtowicz and Ravetz (1999, 2003) and Maxim and van der Sluijs (2007), scientific and social uncertainties are characteristic of post-normal science theory. Jasanoff (2003) calls for a new technology that casts off the old hierarchical constructs to make room for these new science theories. Bradshaw and Borchers (2000) look at the gap between science and government, while Cho (2010) looks at the gap between peer-reviewed scientific literature about CCD and the mass media's portrayal of the issue. These articles and ideologies present an area for inquiry into the communication parameters of the federal government websites that address CCD. Very little prior research looks at the federal website, the information seeker, and CCD information dissemination.

The present study addressed the following research questions:

- Do the websites for the Environmental Protection Agency (EPA), the United States Department of Agriculture (USDA), the United States Fish and Wildlife Service (US FWS), and the United States Geological Survey's (USGS) National Biological Information Infrastructure (NBII), present CCD comprehensively to a spectrum of citizen user groups?

- What are the information topics available on these four websites?

- What material is missing or incomplete from the websites? 


\section{Methodology}

The research method included a content analysis comparing information content on the four web pages, using the information seeker requirements based on the GIV framework of citizen user needs.

The four federal government entities included:

- United States Department of Agriculture (USDA)

- Environmental Protection Agency (EPA)

- National Biological Information Infrastructure (NBII) ${ }^{1}$ from the United States Geological Survey (USGS)

- United States Fish and Wildlife Service (US FWS)

\section{Step 1}

At the home page for each federal government organization's website, ${ }^{2}$ the author entered the query "CCD" in the available search box, thereby conducting a general search for a web page with CCD information. "CCD" was chosen instead of Colony Collapse Disorder because an information seeker often knows only the abbreviation, not the full name of the phenomenon. Searching under the initials also ruled out other "colonies" and "disorders" which might have appeared.

Each site directed the user to a list of options. The author chose the first internal webpage that had CCD in the title from the list of options. In many cases the first choices were PDF files or the link redirected the user to other places, but in each case the author determined the location of the main page of CCD information. $^{3}$

\footnotetext{
${ }^{1}$ At the onset of research in January 2011 and the initial webpage analysis in May 2011, the NBII was a fully functioning entity. The program was cancelled in the fall of 2011. The NBII website is no longer available from the original source URL; however, archived copies of the site are available from Stanford University's Fugitive U.S. Agencies collection, cataloged at http://archive-it.org/collections/2361 . The situation is described by J. R. Jacobs at http://freegovinfo.info/node/3613 .

${ }^{2}$ The four organizations' website home portals were:

- USDA: http://www.usda.gov/wps/portal/usda/usdahome

- EPA: http://www.epa.gov/

- NBII: http://www.nbii.gov/portal/server.pt?open=512\&objID=236\&mode $=2 \&$ cached $=$ $\underline{\text { true }}$

- US FWS: http://www.fws.gov/

${ }^{3}$ The webpages were:

- USDA: http://www.ars.usda.gov/News/docs.htm?docid=15572

- EPA: http://www.epa.gov/pesticides/about/intheworks/honeybee.htm

- NBII:http://www.nbii.gov/portal/server.pt/community/threats to native species 1850/colony collapse disorder \%28ccd\%29/3656
} 


\section{Step 2}

For each organization, the author took an inventory of the contents of the CCD page. This inventory included all PDF documents and links to other pages both internal and external to the organization. This inventory defined the scope of the possible analysis. The author defined each webpage's information as the contents of the main page plus any material available for download and any links (either to another webpage or another website) located within the main page. This parameter was chosen to clearly define a specific window of information and to keep the amount of material manageable for analysis.

\section{Step 3}

The author conducted a comparison of the four federal organizations based on their websites' CCD information. This comparison evaluated similarities and differences in the content each entity provided and identified some possible specific roles and focal points of each organization. The author needed to clarify the general differences before assessing specific topics and types of materials available to the user. The author compared five general defining characteristics of each site. These characteristics were based on the initial observations of the material.

These characteristics are:

- The agency's definitive role within the U.S. government, as defined by the government

- The organization's primary focus or specialization

- A summary of the type of information the agency provided

- The agency's partnerships or affiliations

- The amount of internal and external links

\section{Step 4}

The author explored the content gathered from the inventories. An analysis of content similarities from the existing material facilitated identification of several specific types of content. From this inventory, the author developed a clear picture of what content each website provided and exposed areas where content was lacking.

The types of content identified included:

- Basic information

- Frequently asked questions

- US FWS: http://www.fws.gov/pollinators/Features/CCD.html 
- Latest news and features

- Action plan or strategy

- Progress reports

- Multimedia information (photos, videos, podcasts, webinars)

- Links to external sites

- Links to internal pages

- Interactivity or interactive content

- Personal contact or administrator information

- Date the webpage was last updated

\section{Step 5}

In conjunction with the content type, the author identified content format as another area for analysis. Format is important because different user groups prefer and require specific formats. The author found and recorded several formats for future analysis and discussion.

Formats included:

- PDF files

- Sidebar lists

- Text boxes

- Paragraph text embedded on the page

- Hypertext

- Hyperlink

- JPEG/image file

- Audio file

- Data file (Microsoft Excel, etc.)

\section{Step 6}

The author chose one content type to compare the different topics each webpage discussed. The author chose "basic information" from the CCD page because it was available from all four sites in a simple format. The author compared the basic information for each organization and developed categories of topics. The author organized the subject matter based on paragraph sub-headings or beginning phrases when the sub-headings were not available. This comparison gave the author an overview of the differences and similarities in the scope of the subjects addressed by each agency website.

The information topics included:

- Introduction

- Issues (possible causes and solutions) 
- Controversy

- Myths

- Research

- Institutional focus

- Resources

- Public involvement

\section{Step 7}

At this point, the author added the citizen spectrum into the analysis. The author used Eschenfelder and Miller (2007)'s GIV framework to match content type and topic with a variety of user groups. The author chose this framework because it classified citizens into four areas on a continuum of increasingly deeper engagement within the process of environmental problem-solving and policymaking. The study provided an example of the needs and activities of four user types. Table 1 defines the four citizen users' needs.

Table 1

Definitions of user action and information needs

\begin{tabular}{|l|l|l|l|l|}
\hline GIV framework & Private Citizen & $\begin{array}{l}\text { Attentive } \\
\text { Citizen }\end{array}$ & $\begin{array}{l}\text { Deliberative } \\
\text { Citizen }\end{array}$ & Citizen Publisher \\
\hline $\begin{array}{l}\text { User activity } \\
\text { and needs }\end{array}$ & $\begin{array}{l}\text { Information for } \\
\text { individual } \\
\text { citizens to make } \\
\text { private decisions } \\
\text { or take private } \\
\text { actions }\end{array}$ & $\begin{array}{l}\text { Two-way flow } \\
\text { of info; } \\
\text { assessment of } \\
\text { agencies' } \\
\text { policies and } \\
\text { performance; } \\
\text { government } \\
\text { collects citizen } \\
\text { opinion for } \\
\text { feedback to } \\
\text { experts }\end{array}$ & $\begin{array}{l}\text { Information to } \\
\text { formulate } \\
\text { articulate and } \\
\text { defend in public } \\
\text { forum; need a } \\
\text { range of facts } \\
\text { and } \\
\text { interpretations } \\
\text { for informed } \\
\text { debate }\end{array}$ & $\begin{array}{l}\text { Horizontal / multi- } \\
\text { dimensional flow of } \\
\text { information, civil } \\
\text { society organization; } \\
\text { government } \\
\text { information is not the } \\
\text { focus but supports } \\
\text { and reflects the } \\
\text { seeker's views. }\end{array}$ \\
\hline
\end{tabular}

Note: From left to right, the type of information for each type of citizen user is defined. The explanation includes the user activity and the type of information this requires. For an in-depth discussion of the characteristics of the citizen user groups please see Eschenfelder \& Miller, 2007, Table 3, p. 29.

\section{Step 8}


The GIV description was used to name specific types of CCD information seekers within each category. In making customized connections, the author put the needs of the user into the context of CCD information seekers. Table 2 contextualizes citizen user needs.

\section{Step 9}

Two of the federal organizations defined certain user groups on their homepage; however, these defined user groups did not appear in all facets of the websites and did not appear on the CCD information pages. The categories did help the author define the users by providing the perspective of the particular organization. The organizations' designated citizen categories were considered and matched to the four types of citizens in the GIV framework.

Table 2

Roles specific to the CCD information-seeking citizen

\begin{tabular}{|c|c|c|c|c|}
\hline GIV framework & Private Citizen & $\begin{array}{l}\text { Attentive } \\
\text { Citizen }\end{array}$ & $\begin{array}{l}\text { Deliberative } \\
\text { citizen }\end{array}$ & Citizen Publisher \\
\hline $\begin{array}{l}\text { Application to } \\
\text { information } \\
\text { seeker for CCD } \\
\text { information }\end{array}$ & $\begin{array}{l}\text { Teachers, } \\
\text { consumers, } \\
\text { gardeners, small } \\
\text { business } \\
\text { owners, } \\
\text { hobbyist } \\
\text { farmers and } \\
\text { beekeepers }\end{array}$ & $\begin{array}{l}\text { Small scale } \\
\text { farmers and } \\
\text { hobbyist } \\
\text { beekeepers, } \\
\text { consumer } \\
\text { advocate, } \\
\text { journalist } \\
\text { (editorial), } \\
\text { land use and } \\
\text { planning } \\
\text { experts }\end{array}$ & $\begin{array}{l}\text { Environment } \\
\text { analysts, } \\
\text { economic and } \\
\text { industry } \\
\text { associates, } \\
\text { grassroots } \\
\text { organizations, } \\
\text { community level } \\
\text { leaders (e.g., } \\
\text { mayor), } \\
\text { beekeepers, } \\
\text { journalist (non- } \\
\text { editorial) }\end{array}$ & $\begin{array}{l}\text { Researchers } \\
\text { affiliated with } \\
\text { universities and } \\
\text { institutions, non- } \\
\text { governmental } \\
\text { organizations, policy } \\
\text { analysts, agricultural } \\
\text { engineers and } \\
\text { apicultural experts, } \\
\text { state inspectors, } \\
\text { scientists from other } \\
\text { fields, chemists }\end{array}$ \\
\hline
\end{tabular}

Note: From left to right, the citizen users are defined according to their particular roles within the context of CCD and their resulting information needs. The type and scope changes as the roles become more deeply involved with CCD research, maintenance and/or legislation.

\section{Step 10}

The author's final comparison took the four citizen categories of the GIV framework, now customized into CCD information seeking groups, and applied the types of information for each group as recommended by Eschenfelder and Miller (2007, p. 64). The author completed the comparison by comparing the amount of content types available on each website to the corresponding citizen 
descriptions. This step gave a picture of general gaps in the content type required by each user group.

\section{Results and Findings}

\section{Do the Websites for the EPA, the USDA, the US FWS, and the USGS's NBII Present Colony Collapse Disorder Comprehensively to a Spectrum of Citizen User Groups?}

After completing the steps for the content analysis, the results show that the four federal government websites do cover many aspects of CCD information; however, the websites' information was not comprehensive as defined by the framework of the analysis. Table 3 shows the information content of each entity's website by relating the content to the spectrum of citizen user groups defined by the GIV framework. The US FWS and the NBII each leave an entire category of user without the information needed.

Table 3

Information contents organized by each federal entity by user group

\begin{tabular}{|l|l|l|l|l|}
\hline & Private Citizen & Attentive Citizen & Deliberative citizen & $\begin{array}{l}\text { Citizen- } \\
\text { Publisher }\end{array}$ \\
\hline USDA & $\begin{array}{l}10 \text { core } \\
\text { paragraphs } \\
1 \text { link to info } \\
5 \text { multimedia }\end{array}$ & $\begin{array}{l}\text { 2 progress reports } \\
1 \text { action plan }\end{array}$ & $\begin{array}{l}8 \text { internal links } \\
2 \text { external links to } \\
\text { info }\end{array}$ & $\begin{array}{l}10 \text { links } \\
1 \text { assist: contact } \\
\text { info }\end{array}$ \\
\hline EPA & $\begin{array}{l}7 \text { core paragraphs } \\
3 \text { pesticide } \\
\text { specific } \\
1 \text { photo }\end{array}$ & $\begin{array}{l}1 \text { USDA action } \\
\text { plan } \\
1 \text { strategy }\end{array}$ & $\begin{array}{l}5 \text { internal links } \\
2 \text { external links }\end{array}$ & $\begin{array}{l}\text { 5 links } \\
\text { partnership } \\
\text { NAPPC } \\
1 \text { assist- pest } \\
\text { info \# }\end{array}$ \\
& $\begin{array}{l}2-3 \text { core } \\
\text { paragraphs } \\
1 \text { photo }\end{array}$ & $\begin{array}{l}1 \text { clear link to CRS } \\
\text { report (2007) }\end{array}$ & $\begin{array}{l}41 \text { links to external } \\
\text { info }\end{array}$ & \\
\hline NBII & $\begin{array}{l}2-3 \text { core } \\
\text { paragraphs } \\
1 \text { photo }\end{array}$ & & $\begin{array}{l}1 \text { disc of research } \\
9 \text { internal links } \\
4 \text { external links }\end{array}$ & $\begin{array}{l}1 \text { partnership } \\
\text { implied } \\
4 \text { external links }\end{array}$ \\
\hline US FWS & & & & \\
\end{tabular}

Note: From left to right, a menu of the contents of each CCD web page that are most applicable to the citizen user group is shown.

\section{What Are the Information Topics Available on These Four Webpages?}


Of the seven information topics listed in step six of the analysis, the most covered topics include the introduction, the issues of potential causes and solutions, research, and institutional focus. All organizations mentioned and supplied a link to the USDA Agricultural Research Service (ARS) main CCD page. The US FWS and the USDA both mentioned and provided a link or information about the North American Pollinator Protection Campaign (NAPPC), a not-for profit affiliate of other biodiversity networks that initiates research and data collection to inform global policy.

\section{What Material is Missing or Incomplete?}

The author identified incomplete and/or missing information in four content areas.

Current information. The governmental webpages and the websites to which they link were all at least a year out of date, except for the EPA website, which was current. The majority of the articles and reports were from 2007. The US FWS had the least current materials, with information about meetings from 2005. It was not possible to tell when the NBII was last updated. The USDA and the EPA both had material last dated 2009.

Shared resources and links to partnerships. No organization directly mentioned any other of the organizations besides the USDA. The USDA provides several internal links to other related information, yet only one external resource link.

Public engagement resources. No website directly discussed participation tools for citizen involvement or provided specialized resources for communities. The author identified a lack of assistance for users who want to report information or request specific information needs (besides organizational contact information.) Table 3 displays data from the study organized according to user type.

Discussion about myths and controversial topics. Myths and controversial issues were not mentioned by any of the entities except for the USDA. The USDA page had a brief explanation about research on the myth of CCD and cell phone signals, clarifying the myth and the current understanding of the issue among apicultural experts.

\section{Discussion}


The data collected from this study of online information regarding CCD shows strengths and weaknesses of the information available to citizen user groups. The US FWS did not have any information applicable to the category of attentive citizen. According to the framework, this translates to a possible gap in information from the US FWS CCD page for information seekers such as hobbyist beekeepers, small-scale farmers, and other citizens who have a moderate level of involvement in relation to the phenomenon. The USGS's NBII did not have any information catering to the specific information needs of the citizenpublisher group. This translates to a possible gap in the information available from the NBII for individuals who have a very high level of involvement or need for involvement.

The USDA has the most information overall for all the user groups. This finding is consistent with the linking practices of the other entities. The EPA, the US FWS and the USGS'S NBII all provide links to the specific USDA webpage that was assessed in the study. Further analysis is needed to determine whether this finding suggests that the USDA is considered an authority within the information topic that was used (Basic information).

At the time of publication, two potential limitations of this study have been identified and require additional analysis within the framework that was developed for this exploratory study. The first is that the differences in the organizations' roles within the government do influence the funding, interpretation, and transmission of web-related information on CCD. In future extensions of this research, the author will work to include definitions of these differing responsibilities of the entities to account for variations and nuances of structure and function that exist but are not well known and cannot be assessed using content analysis. The second potential limitation is that the study was subject to the author's bias because it was a personal endeavor and the author applied his working knowledge of the phenomenon to create the applied criteria. A more in-depth study of information types, topics, and formats that are ubiquitous among the CCD webpage information will be conducted in a future study to reduce this limitation.

\section{Conclusion}

This introductory exploration seeks to understand the landscape of governmental information available that addresses Colony Collapse Disorder. The purpose of the exploration is to understand the types, topics, and formats of information available to a spectrum of users with specific information needs and to address the comprehensiveness of the information available. The framework for analysis was developed and tested as a determination of validity for future use in a larger study by the author in the spring of 2012. This initial study and the ten-step process 
uncovered three areas to explore using a more complex derivation of the research process. The three findings include: the lack of current information, the need for network landscape mapping to understand the nuances of the connections between the entities, and the lack of interactivity and public engagement. The lack of current information seen in the dates on the webpages suggests that there is less attention overall to reporting the latest news to the public. Additionally, information seekers may run into repetition of information resources that are not suitable to their specific needs. Finally, the lack of interactivity and public engagement indicates that the public is not involved in discussion and deliberation of an issue that impacts them significantly. The information needs of the user groups will remain unclear if avenues for requests and comments are not available.

These three findings set the stage for the author's future study on the information provision related to the CCD phenomenon. The focus will be directed to the areas of content previously addressed, with the addition of a comprehensive analysis of clearly defined information types, topics, and formats. Discussion of Information Quality (IQ) aspects of website material is needed. IQ elements, including accuracy, source authority, currency, design and usability, and interactivity, will be defined by an IQ literature review and operationalized for contextual congruency. In addition, the author determined that the assessment should cover additional popular sources of information to compare and contrast with the government agency. Wikipedia's CCD page will be the fifth webpage for analysis. Finally, social network analysis will be applied using the external links of each entity. The study made clear that there was no recognized central source of CCD information online. This added analysis of the information network as a whole, combined with the relationships between the information providers, will present a more complex view of CCD information on the web.

\section{References}

Bradshaw, G., and Borchers, J. (2000). Uncertainty as information: Narrowing the science policy gap, Ecology and Society, 4(1), 1-12.

Byrne, P. F., Namuth, D. M., Harrington, J., Ward, S. M., Lee, D. J., and Hain, P. (2002). Increasing public understanding of transgenic crops through the World Wide Web. Public Understanding of Science, 11(3), 293-304. 
Cho, A. (2010). Silence of the bees: A study of scientific representation in media, Berkeley. Retrieved from nature.berkeley.edu/classes/es196/projects/2010final/ChoA_2010.pdf

Environmental Protection Agency. (2011). Pesticide issues in the works: Honeybee colony collapse disorder, About Pesticides. United States Environmental Protection Agency Website. Retrieved from http://www.epa.gov/opp00001/about/intheworks/honeybee.htm

Eschenfelder, K., \& Miller, C. (2007). Examining the role of web site information in facilitating different citizen-government relationships: A case study of Chronic Wasting Disease Web sites. Government Information Quarterly, 24(1), 64-88.

Fischer, F. (2000). Citizens, experts, and the environment: The politics of local knowledge. Durham and London: Duke University Press.

Funtowicz, S., Martinez-Alier, J., Munda, G., \& Ravetz, J. (1999). Information tools for environmental policy under conditions of complexity. Luxembourg: European Environmental Agency.

Funtowicz, S., \& Ravetz J. (2003) Post-normal science, Institute for the Protection and Security of the Citizen (IPSC), European Commission Joint Research Centre (EC-JRC), TP 268, 21020 Ispra (VA) ñ- Italy. Research Methods Consultancy, London, England.

Gregory, J., \& Miller, S. (1998). Science in public: Communication, culture, and credibility. Cambridge: Basic Books.

Jasanoff, S. (2003). Technologies of humility: Citizen participation in governing science. Minerva, 41, 223-244.

Jobe, M. (2006). Going local: Environmental information on the Internet, The Haworth Press, Inc. Retrieved from http://www.haworthpress.com/web/REF doi:0.1300/J120v45n94_15

Kaplan, K. (2011). Questions and answers: Colony Collapse Disorder, News and Events. United States Department of Agriculture, Agricultural Research Service. Retrieved from http://www.ars.usda.gov/News/docs.htm?docid=15572. 
Maxim, L., \& van der Sluijs, J. (2007). Uncertainty: Cause or effect of stakeholders' debates? Analysis of a case study: The risk for honeybees of the insecticide Gaucho, Science of the Total Environment, 376, 1-17.

North American Pollinator Protection Campaign. (2007). Honey bee disappearance (CCD) and what you can do. North American Pollinator Protection Campaign. Retrieved from www.pollinator.org/Resources/CCD\%20Response\%20FINAL.pdf

United States Fish and Wildlife Service. (2009) Colony Collapse Disorder, Pollinators. U.S. Fish and Wildlife Service. Retrieved from http://www.fws.gov/pollinators/Features/CCD.html

United States Geological Survey National Biological Information Infrastructure. (2011). Colony Collapse Disorder (CCD) Threats to native species, United States Geological Survey, National Biological Information Infrastructure. Retrieved from http://www.nbii.gov/portal/server.pt?open $=512 \&$ objID $=236 \&$ mode $=2 \&$ cached $=t$ rue (Note: program terminated, more information can be found at: http://www.nbii.gov/termination/index.html) 